\title{
Adsorption of Strontium from an Aqueous Solution by $\mathrm{TiO}_{2}$-Pillared Zeolite
}

\author{
Kris Tri Basuki ${ }^{*}$, Muni Fatuzzahroh ${ }^{1}$, Dhita Ariyanti1 ${ }^{1}$, Andri Saputra ${ }^{2}$ \\ ${ }^{1}$ Department of Nuclear Chemical Engineering, STTN-BATAN, Jl. Babarsari, Yogyakarta 55821, Indonesia \\ ${ }^{2}$ Politeknik ATK Yogyakarta, Jl. Prof. Dr. Wirdjono Prodjodikoro, Bantul, Yogyakarta 55188, Indonesia
}

\begin{abstract}
Strontium is a heavy metal that is commonly found in many groundwater systems because of migration from historic nuclear waste storage sites. Its radiation effect can cause bone cancer, tumors, and leukemia. An economical and the most effective method to remove heavy metals from aqueous solutions is adsorption. In this study, we synthesized a $\mathrm{TiO}_{2}$-pillared zeolite to improve the adsorption efficiency of the zeolite. $\mathrm{The}^{\mathrm{TiO}_{2}}$-pillared zeolite was synthesized via the pillarization process. Adsorbent characterization was done using X-ray powder diffraction, which showed that $\mathrm{TiO}_{2}$ was successfully pillared. Fourier-transform infrared spectroscopy showed a shift in the peak at a wavenumber of $3425.70 \mathrm{~cm}^{-1}$, which can be attributed to the addition of $\mathrm{TiO}_{2}$. A parameter study conducted using a batch experiment showed that optimal strontium adsorption took place at $\mathrm{pH} 5$ and contact time of $80 \mathrm{~min}$. The Freundlich adsorption isotherm fitted the experimental data well, illustrating the adsorption of strontium as being non-ideal, reversible, and multilayer adsorption that occurs on the heterogeneous surface of the $\mathrm{TiO}_{2}$-pillared zeolite. $\mathrm{A}$ thermodynamic study indicated that strontium adsorption on the $\mathrm{TiO}_{2}$-pillared zeolite was an endothermic process, takes place spontaneously, and is quite stable.
\end{abstract}

Keywords: Adsorption; Strontium; Titanium dioxide; Zeolite

\section{Introduction}

In Indonesia, nuclear technology usage has increased in the fields such as agriculture, advanced materials, food, nuclear medicine, and industrial manufacturing. However, this has resulted in an increase in radioactive waste. Toxicological and radiological effects caused by radioactive wastewater on human health and the ecosystem are serious concerns. Radioactive wastewaters commonly contain strontium, which is a pure beta emitter, has a half-life of 28.8 years, and is commonly found in groundwater systems near nuclear storage sites (Pathak, 2017). Strontium enters the human body through ingestion, and its radiation effects include bone cancer, tumors, and leukemia (Herhady et al., 2003). Because of its high radiological toxicity and relatively long half-life, strontium removal from aqueous solutions is of great interest.

Strontium removal has been attempted using membrane separation, ion exchange, chemical precipitation, and adsorption. For low-strength wastewaters, in particular, most of these processes are inefficient and expensive (especially ion exchange) (Hasan et al., 2019). In contrast, adsorption has been proven to be effective in reducing the concentration Research on strontium adsorption has been carried out using several adsorbents, such

${ }^{*}$ Corresponding author's email: kristri_basuki@batan.go.id, Tel.: +62-274-484085; Fax: +62-274-489715 doi: 10.14716/ijtech.v12i3.4376 
polyacrylonitrile(PAN)-zeolite (Yusan and Erenturk, 2011), Ca-alginate (Song et al., 2013), SBA-15 (Zhang et al., 2015), Chitosan-Fuller's earth beads (Hasan et al., 2019), and $\mathrm{K}_{2} \mathrm{Ti}_{4} \mathrm{O}_{9}$ (Lee et al., 2018).

Adsorption using zeolites is a promising method. Their ion exchange capacity, selectivity (Taamneh and Sharadqah, 2016), chemical stability, low cost (Abdel-Rahman et al., 2011), and high adsorption capacity (Hong, et al., 2018, Sudibandriyo and Putri, 2020) allow zeolites to have a high adsorption performance. Research on strontium adsorption using PAN-zeolite composites has been conducted by Yusan and Erenturk (2011), but the adsorption capacity (strontium uptake) was very low $(0.011 \mathrm{mg}$ strontium / g adsorbent). Efforts to increase the zeolite's adsorption capacity were taken by pillaring the zeolite with certain compounds, such as $\mathrm{TiO}_{2}$. $\mathrm{TiO}_{2}$ nanoparticles perform well as adsorbents as evidenced from previous studies for the absorption of tellurium (Zhang et al., 2010), chromium (VI) (Ren et al., 2017), and copper (II) (Thahir et al., 2018). This study aims to synthesize and characterize the $\mathrm{TiO}_{2}$-pillared zeolite and evaluate its adsorption capacity for strontium adsorption. The change in the interlayer distance or basal spacing in the $\mathrm{TiO}_{2}-$ pillared zeolite was determined using X-ray powder diffraction (XRD). Fourier-transform infrared (FTIR) spectroscopy was used to determine the effect of adding $\mathrm{TiO}_{2}$ on the bonds in the zeolite structure. A batch experiment was conducted to evaluate the adsorption capacity. Freundlich and Langmuir adsorption isotherms and thermodynamic studies were implemented to comprehensively understand the adsorption process.

\section{Methods}

Mordenite zeolite and distilled water were purchased from CV. Progo Mulyo, Yogyakarta, Indonesia. Chemicals used for the synthesis of the $\mathrm{TiO}_{2}$-pillared zeolite included sodium hydroxide, absolute ethanol, hydrogen chloride, and nitric acid, which were purchased from Merck, Darmstadt, Germany. Chemical used for adsorption was strontium nitrate, which was obtained from Merck, Darmstadt, Germany.

Instruments used for the characterization of the $\mathrm{TiO}_{2}$-pillared zeolite were the $\mathrm{TM}$ 3000 Hitachi scanning electron microscope (SEM), X-ray diffractometer by PANAnalytical Type X'pert PRO, and Thermo Scientific Nicolet iS10 FTIR spectrometer. The final concentrations of strontium were measured using the atomic absorption spectrometer, 2Solar Series Thermo Electron Corp.

\subsection{Zeolite Activation}

The zeolite was crushed and sieved using a 300 mesh sieve. In a beaker, $100 \mathrm{~g}$ of zeolite was added to $200 \mathrm{~mL}$ of $1 \mathrm{M}$ hydrogen chloride. At steady room temperature, the mixture was stirred for $3 \mathrm{~h}$. The mixture was rinsed to neutral $\mathrm{pH}$ using distilled water. Then, it was dried at $250^{\circ} \mathrm{C}$ for $4 \mathrm{~h}$ in a drying oven. This procedure was followed according to that reported by Sani et al. (2009).

\subsection{Synthesis of $\mathrm{TiO}_{2}$-Pillared Zeolite}

To a $100 \mathrm{~mL}$ of absolute ethanol, $100 \mathrm{~g}$ of activated zeolite and $5 \mathrm{~g}$ of $\mathrm{TiO}_{2}$ were added and continuously stirred for $5 \mathrm{~h}$ at steady room temperature. The formed photocatalyst was separated using the Whatman 41 filter. The mixture was then dried at $120^{\circ} \mathrm{C}$ for $5 \mathrm{~h}$ in a drying oven and calcined in a furnace at $500^{\circ} \mathrm{C}$ for $5 \mathrm{~h}$. Then, the obtained $\mathrm{TiO}_{2}$-pillared zeolite was characterized using SEM, XRD, and FTIR spectroscopy. According to Nikazar et al. (2007), the proposed incorporation of $\mathrm{TiO}_{2}$ into the zeolite is as shown in Figure 1. 


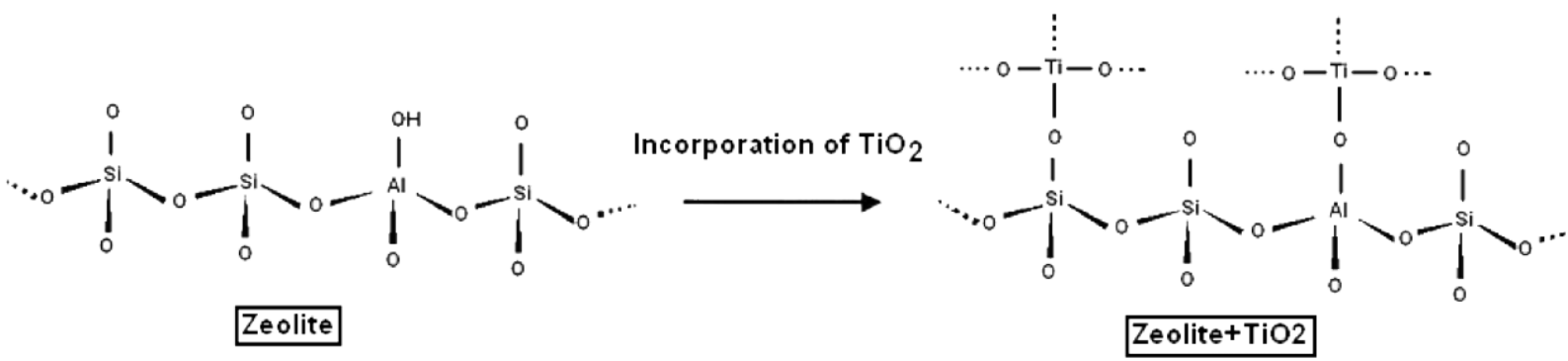

Figure 1 Proposed incorporation of $\mathrm{TiO}_{2}$ on the zeolite (Nikazar et al., 2007)

\subsection{Batch Experiment to Analyze Strontium Adsorption}

The effects of the adsorption parameters were analyzed via a batch experiment in triplo. A stock solution of $100 \mathrm{ppm}$ of strontium was prepared by dissolving $0.241 \mathrm{~g}$ of strontium nitrate in $1 \mathrm{~L}$ of distilled water. $10 \mathrm{~mL}$ of strontium stock solution (at pH 5) was tested with $0.1 \mathrm{~g}$ of the $\mathrm{TiO}_{2}$-pillared zeolite at $25^{\circ} \mathrm{C}$ for different contact times $(20,40,60$, 80 , and $100 \mathrm{~min})$. The steps were repeated at different $\mathrm{pH}(4,5,6,7$, and 8$)$ and various strontium concentrations $(20,40,60,80,100,120,140$, and $160 \mathrm{ppm})$. Atomic absorption spectroscopy (AAS) at a wavelength of $460.7 \mathrm{~nm}$ was used to measure the final concentrations of strontium (Qiu et al., 2018).

Adsorption isotherms were obtained and thermodynamic studies were conducted for the adsorption observed in the batch experiment conducted in triplo. $10 \mathrm{~mL}$ of strontium stock solution (optimal $\mathrm{pH}$ was found to be 5) was tested with $0.1 \mathrm{~g}$ of the $\mathrm{TiO}_{2}$-pillared zeolite $25^{\circ} \mathrm{C}$ for $100 \mathrm{~min}$. This was repeated at various strontium concentrations $(20,40$, $60,80$, and $100 \mathrm{ppm})$ and temperatures $\left(25,30\right.$, and $\left.33^{\circ} \mathrm{C}\right)$. AAS at a wavelength of 460.7 $\mathrm{nm}$ was used to measure the final concentrations of strontium (Qiu et al., 2018).

\section{Results and Discussion}

\subsection{Characterization of the $\mathrm{TiO}_{2}$-Pillared Zeolite}

The $\mathrm{TiO}_{2}$-pillared zeolite was characterized by SEM, XRD, and FTIR spectroscopy. The zeolite FTIR spectra are illustrated in Figure 2. Figure 2a shows that $\mathrm{O}-\mathrm{H}$ stretching vibrations correspond to the wavelength of $3413.12 \mathrm{~cm}^{-1}$. The adsorption at wavenumber $1647.26 \mathrm{~cm}^{-1}$ indicates the functional groups of $\mathrm{OH}$ and the adsorption at wavenumbers $1047.38 \mathrm{~cm}^{-1}$ and $796.63 \mathrm{~cm}^{-1}$ indicate the presence of functional groups in the form of $0-$ $\mathrm{Si}-\mathrm{O}$ and $\mathrm{O}-\mathrm{Al}-\mathrm{O}$. The uptake at wavenumber $453.29 \mathrm{~cm}^{-1}$ is a characteristic of Al-O bonds. Whereas the FTIR spectra for the $\mathrm{TiO}_{2}$-pillared zeolite in Figure $2 \mathrm{~b}$ shows a shift in the uptake at wavenumber $3452.70 \mathrm{~cm}^{-1}$, which corresponds to the $\mathrm{O}-\mathrm{H}$ bond adsorption. The uptake at wavenumber $1643.41 \mathrm{~cm}^{-1}$ refers to the functional groups of buckling $\mathrm{OH}$. These FTIR spectroscopy results suggest a very small shift in the spectra between the zeolite and the $\mathrm{TiO}_{2}$-pillared zeolite, which is because they are still in the same range. The shift was caused by the addition of $\mathrm{TiO}_{2}$ as well as the presence of other metals as contaminants in the zeolite such as silicon, aluminum, magnesium, sodium, potassium, calcium, and iron.

Figure 3a shows the SEM images of the zeolite morphology before being pillarized with $\mathrm{TiO}_{2}$. It is clear that there are several impurities mentioned above, making the distribution of $\mathrm{TiO}_{2}$ not clearly visible. In Figure $3 \mathrm{~b}$, clear spots representing $\mathrm{TiO}_{2}$ attached to the surface of the zeolite structures are visible. Thus, the SEM analysis clarifies that $\mathrm{TiO}_{2}$ has been successfully pillarized on the zeolite.

The XRD data in Figure 4a show the zeolite diffraction spectra with diffraction angle $2 \theta$ at $13.50^{\circ}, 19.53^{\circ}, 25.52^{\circ}$, and $27.52^{\circ}$; this is a characteristic of mordenite minerals (M). A characteristic of the clinoptilolite (KI) mineral is found at $9.76^{\circ}$ and $22.14^{\circ}$. Quartz minerals 
give reflection with intensity in the region of $2 \theta$ at $26.42^{\circ}$. Therefore, the zeolite used in this study contains mordenite and clinoptilolite.

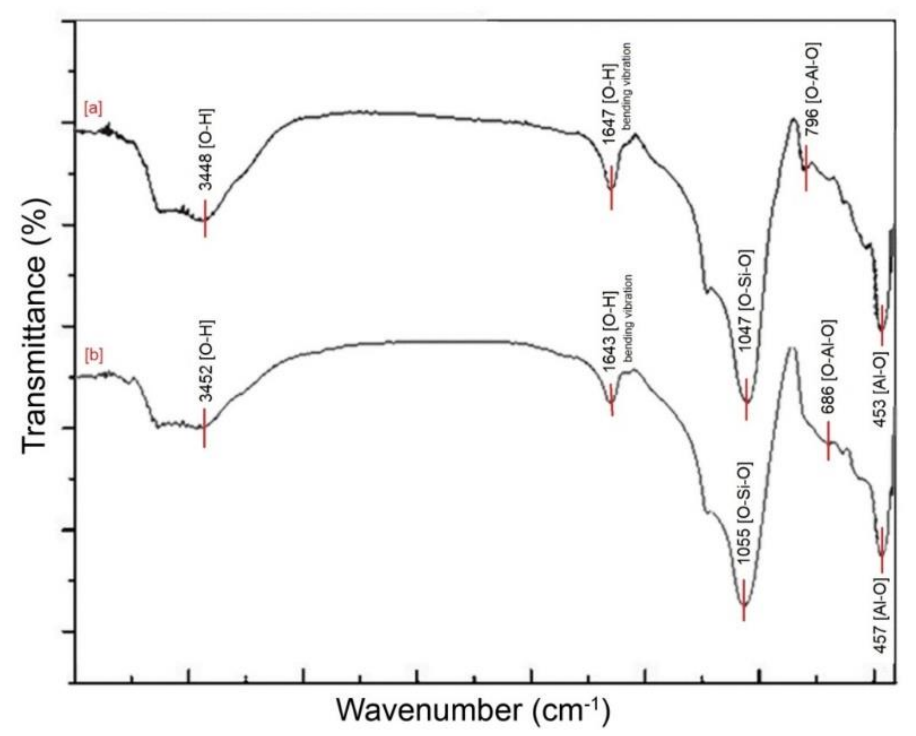

Figure 2 Fourier-transform infrared spectra of the: (a) zeolite; and (b) $\mathrm{TiO}_{2}$-pillared zeolite

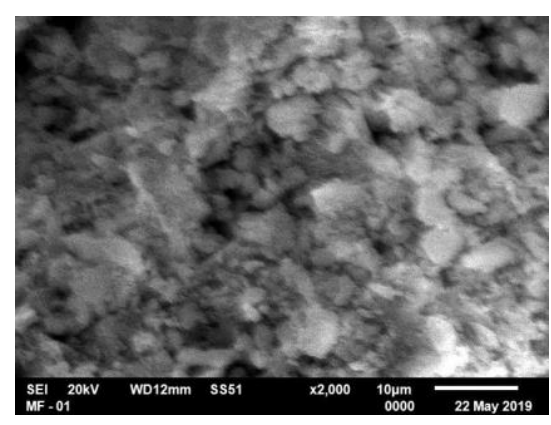

(a)

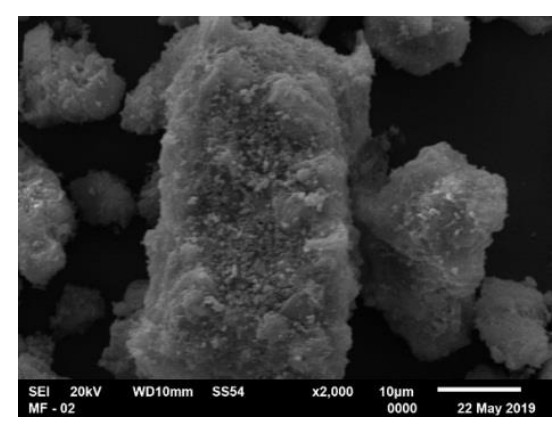

(b)

Figure 3 Scanning electron microscopy images of the: (a) zeolite; and (b) $\mathrm{TiO}_{2}$-pillared zeolite

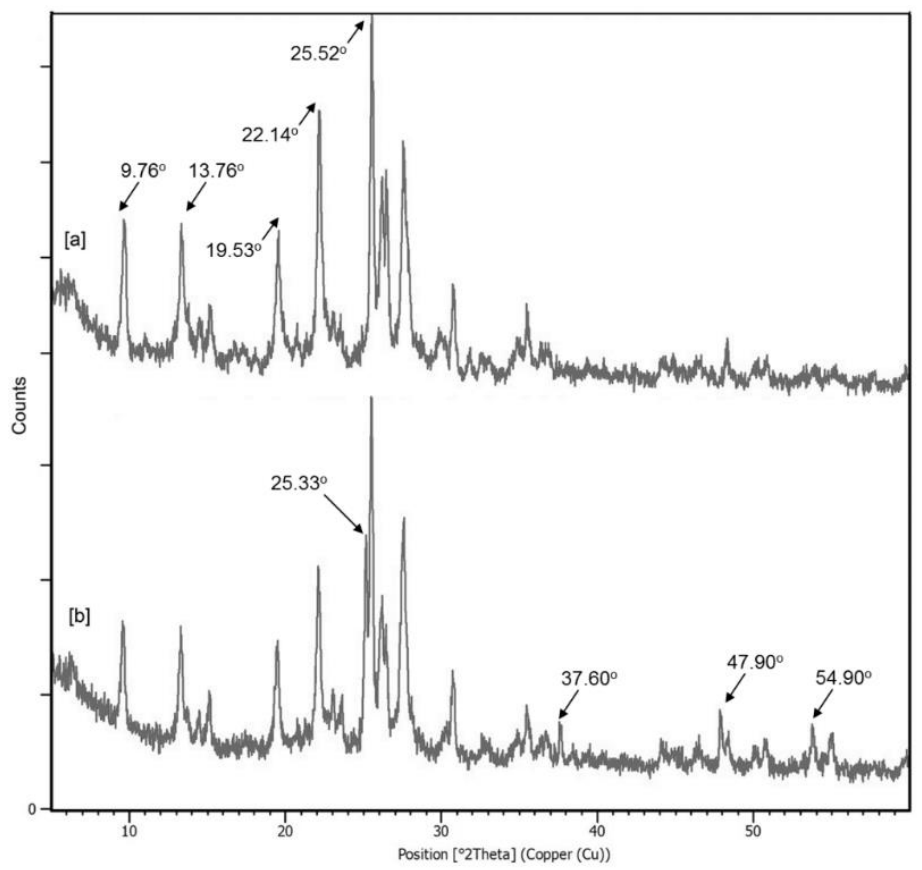

Figure 4 X-ray powder diffraction spectra of the: (a) zeolite; and (b) $\mathrm{TiO}_{2}$-pillared zeolite 
The $\mathrm{TiO}_{2}$-pillared zeolite diffraction spectra illustrated in Figure $4 \mathrm{~b}$ has diffraction angle $2 \theta$ at $25.33^{\circ}, 37.6^{\circ}, 47.9^{\circ}$, and $54.9^{\circ}$, which are characteristic peaks of $\mathrm{TiO}_{2} . \mathrm{TiO}_{2}$ anatase has been used in this study. The crystal structure difference between the anatase and rutile types lies in the distortion and arrangement of the octahedron chain (Pataya et al., 2016). The bond distance of Ti-Ti in anatase is higher than that in rutile. However, the bond distance of $\mathrm{Ti}-\mathrm{O}$ in anatase is lower than that in rutile. $\mathrm{Thus} \mathrm{TiO}_{2}$ anatase has a greater surface area than rutile. In the $\mathrm{TiO}_{2}$-pillared zeolite diffraction spectra, the characteristic peaks of $\mathrm{TiO}_{2}$ reappeared, confirming that $\mathrm{TiO}_{2}$ was immobilized on the surface of the zeolite.

\subsection{Adsorption Study}

\subsubsection{Effect of contact time}

As illustrated in Figure 5a, as the contact time increased, the adsorption capacity $\left(q_{t}\right)$ increased. The adsorption of strontium reached equilibrium in $80 \mathrm{~min}$. It is presumed that the diffusion of strontium from the bulk solution to the $\mathrm{TiO}_{2}$-pillared zeolite surface is controlled by the affinity of strontium toward the active binding sites of the zeolite, justifying the longer time needed for the adsorption to reach equilibrium. The adsorption capacity decreased after $80 \mathrm{~min}$, which is caused by the $\mathrm{TiO}_{2}$-pillared zeolite releasing bonds with the adsorbate (i.e., desorption).

\subsubsection{Effect of initial concentration}

To study the effect of initial strontium concentration, experiments were carried out using $10 \mathrm{~mL}$ of strontium stock solution (at $\mathrm{pH} \mathrm{5}$ ), which was tested with $0.1 \mathrm{~g}$ of $\mathrm{TiO}_{2-}$ pillared zeolite at $298 \mathrm{~K}$ for $80 \mathrm{~min}$. Figure $5 \mathrm{~b}$ illustrates that an increase in the initial concentration of strontium increases the adsorption capacity $\left(q_{t}\right)$. This is in line with the results of Zhao and Asuha (2010) and Ren et al. (2017). As the concentration of strontium increases, the driving force increases to overcome the mass transfer resistance of strontium from the aqueous solution into $\mathrm{TiO}_{2}$-Pillared Zeolite, which increases the adsorption equilibrium of the $\mathrm{TiO}_{2}$-pillared zeolite until it reaches a saturated state. Figure $5 \mathrm{~b}$ also shows that the active sites of the $\mathrm{TiO}_{2}$-pillared zeolite are saturated with strontium when the initial concentration of strontium is $100 \mathrm{ppm}$.

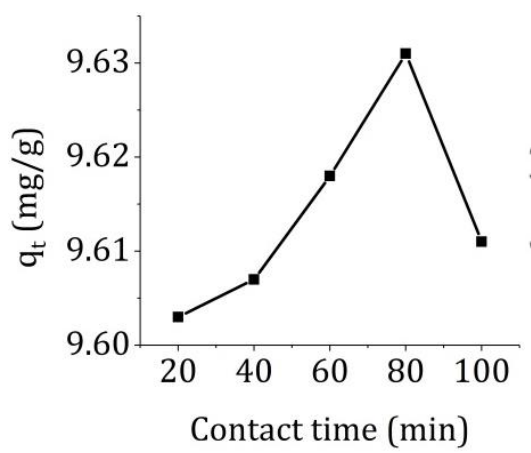

(a)

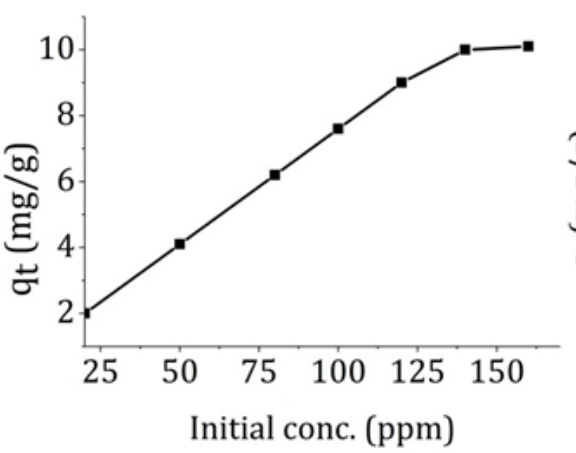

(b)

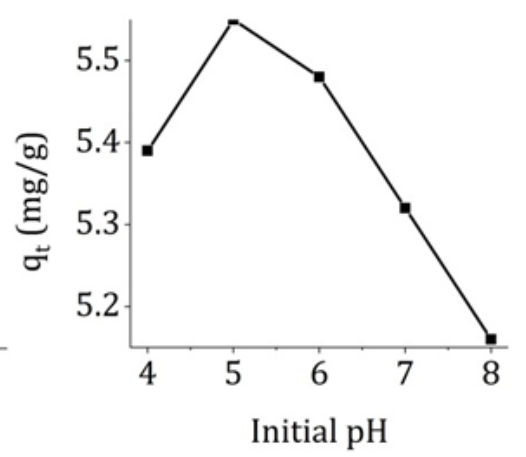

(c)

Figure 5 Effect of: (a) contact time; (b) initial strontium concentration; and (c) initial pH of the aqueous solution on the strontium adsorption by the $\mathrm{TiO}_{2}$-pillared zeolite

\subsubsection{Effect of initial $\mathrm{pH}$ of the solution}

According to Nishiyama et al. (2015), strontium adsorption increases with an increase in $\mathrm{pH}$. To study the effect of initial $\mathrm{pH}$, experiments were conducted using $10 \mathrm{~mL}$ of strontium stock solution with $100 \mathrm{ppm}$ of strontium at $\mathrm{pH}$ ranging from 4 to 8 . This was tested with $0.1 \mathrm{~g}$ of $\mathrm{TiO}_{2}$-pillared zeolite at $298 \mathrm{~K}$ for $80 \mathrm{~min}$. It is evident that the adsorption capacity increases as the $\mathrm{pH}$ increases from 4 to 5 . Lower adsorption capacity values at 
lower $\mathrm{pH}$ is due to the competition of $\mathrm{H}^{+}$ions with strontium ions on the surface of the $\mathrm{TiO}_{2}$ pillared zeolite. In other words, at lower $\mathrm{pH}$, the high ionic strength of $\mathrm{H}^{+}$and other cations compete with strontium to bind with the zeolite, thereby decreasing the adsorption capacity (Alswata et al., 2017).

\subsection{Adsorption Isotherms}

The performance of the $\mathrm{TiO}_{2}$-pillared zeolite was studied for strontium adsorption by using Langmuir (Equation 1) and Freundlich (Equation 2) (Desmiarti et al., 2019) adsorption isotherms. The interaction between strontium and the zeolite, homogeneity of the zeolite, and type of adsorption coverage can be described by these isotherm models (Kyzas et al., 2014).

$$
\begin{gathered}
\frac{C_{e}}{q_{e}}=\frac{1}{q_{m} K_{L}}+\frac{1}{q_{m}} C_{e}, \\
\ln \left(q_{e}\right)=\ln \left(K_{F}\right)+\frac{1}{n} \ln \left(C_{e}\right),
\end{gathered}
$$

where $C_{e}(\mathrm{mg} / \mathrm{L})$ is the equilibrium concentration, $q_{e}(\mathrm{mg} / \mathrm{g})$ is equilibrium adsorption capacity, $q_{m}$ is the adsorption capacity of a complete monolayer $(\mathrm{mg} / \mathrm{g})$, $K_{F}$ is the Freundlich constant $(\mathrm{mg} / \mathrm{g})(\mathrm{L} / \mathrm{mg})^{\mathrm{n}}, K_{L}$ is Langmuir constant $(\mathrm{L} / \mathrm{mg})$, and $1 / n$ is adsorption intensity or the heterogeneity factor, which ranges from 0 to 1 and is a characteristic of surface heterogeneity, indicating higher homogeneity when the value is closer to unity (Dada et al., 2012).

As illustrated in Figure 6, the obtained experimental data were fitted well with the Freundlich model than with the Langmuir model, which illustrates that the adsorption of strontium is defined as adsorption on a heterogeneous surface and as being non-ideal, reversible, and multilayer adsorption onto the heterogeneous surface of $\mathrm{TiO}_{2}$-pillared zeolite. Thus, the monolayer adsorption of strontium is not effective. Previous research by Seidlerová et al., (2016) has shown that $\mathrm{TiO}_{2}$-based adsorbents have a heterogeneous surface, which is in line with our result. Further, the zeolite-based adsorbents researched by Taamneh and Sharadqah (2016) fitted well with the Freundlich model. The $1 / \mathrm{n}$ value for our Freundlich model, shown in Table 2, is 0.5868 , which implies more heterogeneity as it is closer to unity. In this study, the strontium uptake is about $9.632 \mathrm{mg} / \mathrm{g}$, which is lower than that compared with other studies using adsorbents such as SBA-15, Chitosan-Fuller's earth beads, modified bentonite, modified gibbsite, and $\mathrm{K}_{2} \mathrm{Ti}_{4} \mathrm{O}_{9}$, but it is superior to the uptake by PAN-zeolite and Ca-alginate. However, the time for the $\mathrm{TiO}_{2}$-pillared zeolite to reach equilibrium is shorter than that taken by the other adsorbents (see Table 1). This is the advantage of the $\mathrm{TiO}_{2}$-pillared zeolite over the other adsorbents.

Table 1 Strontium uptake using various adsorbents

\begin{tabular}{lccccl}
\hline \multicolumn{1}{c}{ Adsorbent } & $\begin{array}{c}\text { Initial } \\
\text { Concentration } \\
(\mathrm{mg} / \mathrm{L})\end{array}$ & $\begin{array}{c}\text { Contact } \\
\text { Time }(\mathrm{h})\end{array}$ & $\mathrm{pH}$ & $\begin{array}{c}\text { Uptake } \\
(\mathrm{mg} / \mathrm{g})\end{array}$ & \multicolumn{1}{c}{ Reference } \\
\hline PAN-zeolite & $25-175$ & 0.33 & 5 & 0.011 & Yusan and Erenturk (2011) \\
Ca-alginate & $10-500$ & 8 & 7 & 6.700 & Song et al. (2013) \\
SBA-15 & $0-80$ & 5 & 6 & 17.670 & Zhang, et al. (2015) \\
Chitosan-Fuller's & $20-1000$ & 24 & 6.5 & 30.580 & Hasan et al. (2019) \\
earth beads & $5-200$ & 12 & $7-7.5$ & 70.900 & Lee at al. (2018) \\
$\mathrm{K}_{2} \mathrm{Ti}_{4}{ }_{4}$ (20) & $25-150$ & 1.3 & 5 & 9.632 & Present work \\
$\begin{array}{l}\mathrm{TiO}_{2} \text {-pillared } \\
\text { zeolite }\end{array}$ & & & & & \\
\hline
\end{tabular}


Table 2 Isotherm parameters

\begin{tabular}{cccc}
\hline \multicolumn{2}{c}{ Langmuir model } & \multicolumn{2}{c}{ Freundlich model } \\
\hline$q_{m}$ & 13.1547 & $1 / n$ & 0.5868 \\
$K_{L}$ & 0.3436 & $K_{F}$ & 3.3794 \\
$\mathrm{R}^{2}$ & 0.6400 & $\mathrm{R}^{2}$ & 0.9121 \\
\hline
\end{tabular}

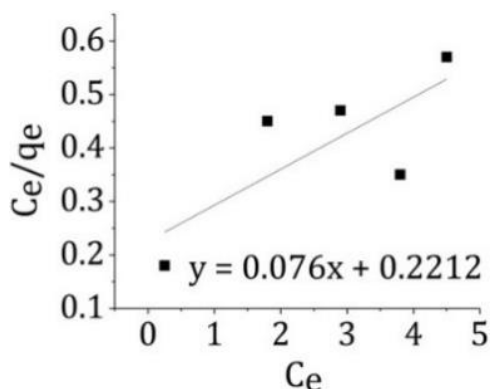

(a)

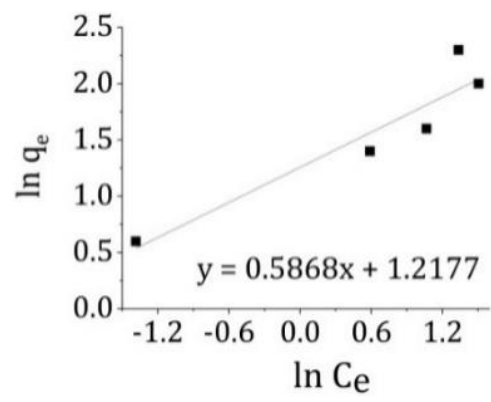

(b)

Figure 6 (a) Langmuir and (b) Freundlich adsorption isotherm models for strontium adsorption by the $\mathrm{TiO}_{2}$-pillared zeolite

\subsection{Adsorption Thermodynamics}

The experimental data were fitted into the linearized Equation (3) to obtain the thermodynamic parameters, namely entropy $\left(\Delta S_{a d s}{ }^{\circ}\right)$ and enthalpy $\left(\Delta H_{a d s}{ }^{\circ}\right.$ ) (Kumar et al., 2010), and the result is illustrated in Figure 7. The $\Delta H_{a d s}{ }^{\circ}$ and $\Delta S_{a d s}{ }^{\circ}$ values were obtained from the slope and intercept of the straight line in the graph, respectively, and the results have been tabulated in Table 2 . The positive value of $\Delta H_{a d s}{ }^{\circ}$ implies that the adsorption is endothermic (Fathy et al., 2016), indicating that the adsorption not suitable to be conducted at low temperatures is. The lower the $\Delta S_{a d s}{ }^{\circ}$ value, the more stable is the process of running the reaction (Prihatiningsih et al., 2020). The obtained $\Delta S_{a d s}{ }^{\circ}$ value is 0.0860 , which indicates that the adsorption is quite stable.

$$
\log \left(\frac{C_{A e}}{C_{e}}\right)=-\frac{\Delta H_{a d s}^{o}}{2.303 R} \frac{1}{T}+\frac{\Delta S_{a d s}^{o}}{2.303 R}
$$

The thermodynamic Gibbs free energy $\left(\Delta G_{a d s}{ }^{\circ}\right)$ was evaluated using Equation 4 at different temperatures $(298,303$, and $313 \mathrm{~K})$, where $R$ is the gas constant $(8.314 \mathrm{~J} / \mathrm{mol} . \mathrm{K})$, and $T$ is the temperature in Kelvin $(K)$ (Hannachi et al., 2014).

$$
\Delta G_{a d s}^{o}=\Delta H_{a d s}^{o}-T\left(\Delta S_{a d s}^{o}\right)
$$

The $\Delta G_{a d s}{ }^{\circ}$ data in Table 3 show that an increase in temperature decreases the $\Delta G_{a d s}{ }^{\circ}$, suggesting that higher temperature is favorable for adsorption (Bhaumik et al., 2012). The negative value of $\Delta G_{a d s}{ }^{\circ}$ indicates that the adsorption takes place spontaneously (Kutahyali and Eral, 2004), and the higher the negative value, the more energetically favorable the adsorption is. This in line with the results of Yusan and Erenturk (2011). They show that strontium adsorption by PAN-zeolite takes place spontaneously. 


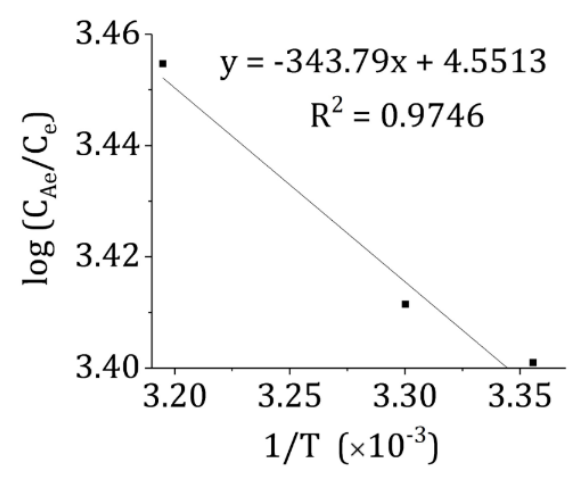

Figure 7 Thermodynamic study on strontium adsorption by the $\mathrm{TiO}_{2}$-pillared zeolite

Table 3 Thermodynamic parameters

\begin{tabular}{crccc}
\hline \multirow{2}{*}{$\begin{array}{c}\text { Temperature } \\
(\mathrm{K})\end{array}$} & $C_{A e} / C_{e}$ & $\Delta \mathrm{G}^{\circ}(\mathrm{kJ} / \mathrm{mol})$ & $\Delta \mathrm{H}^{\circ}(\mathrm{kJ} / \mathrm{mol} . \mathrm{K})$ & $\Delta \mathrm{S}^{\circ}(\mathrm{kJ} / \mathrm{mol})$ \\
\hline 298 & 2518 & -19.3864 & & \\
303 & 2579 & -19.8222 & 6.5826 & 0.0871 \\
313 & 2849 & -20.6936 & & \\
\hline
\end{tabular}

\section{Conclusions}

The zeolite was successfully pillared by $\mathrm{TiO}_{2}$. Diffraction angle $2 \theta$ peaks of $\mathrm{TiO}_{2}$ were found at $25.33^{\circ}, 36.7^{\circ}, 47.9^{\circ}$, and $54.9^{\circ}$. The FTIR spectra showed that the shift at wavenumber $3425.70 \mathrm{~cm}^{-1}$ occurs due to the addition of $\mathrm{TiO}_{2}$. Based on the batch experiment results, the best parameters for strontium adsorption were found to be $\mathrm{pH} 5$ and contact time of $80 \mathrm{~min}$. The adsorption of strontium by the $\mathrm{TiO}_{2}$-pillared zeolite is defined as adsorption on a heterogeneous surface and as being non-ideal, reversible, and multilayer adsorption. Although the adsorption capacity is low, the thermodynamic study indicated that the adsorption of strontium onto $\mathrm{TiO}_{2}$ pillared zeolite was an endothermic process that takes place spontaneously and is quite stable. For future work, the adsorption capacity needs to be increased, which can be accomplished by reducing the size of the pillared $\mathrm{TiO}_{2}$ to allow more area for strontium to be absorbed.

\section{References}

Abdel-Rahman, R.O., Ibrahium, H.A., Yung-Tse, H., 2011. Liquid Radioactive Wastes Treatment: A Review. Water, Volume 3(2), pp. 551-565

Alswata, A.A., Ahmad, M.B., Al-Hada, N.M., Kamari, H.M., Hussein, M.Z.B., Ibrahim, N.A., 2017. Preparation of Zeolite/Zinc Oxide Nanocomposites for Toxic Metals Removal from Water. Results in Physics, Volume 7, pp. 723-731

Bhaumik, R., Mondal, M.K., Das, B., Roy, P., Pal, K.C., Das, C., Baneerjee, A., Datta, J.K., 2012. Eggshell Powder as an Adsorbent for Removal of Fluoride from Aqueous Solution: Equilibrium, Kinetic and Thermodynamic Studies. European Journal of Advanced Chemistry Research, Volume 9(3), pp. 1457-1480

Dada, A.O., Olalekan, A.P., Olatunya, A.M., Dada, O., 2012. Langmuir, Freundlich, Temkin and Dubinin-Radushkevich Isotherms Studies of Equilibrium Sorption of $\mathrm{Zn}^{2+}$ Onto Phosphoric Acid Modified Rice Husk. IOSR Journal of Applied Chemistry, Volume 3(1), pp. 38-45 
Desmiarti, R., Trianda, Y., Martynis, M., Viqri, A., Yamada, T., Li, F., 2019. Phenol Adsorption in Water by Granular Activated Carbon from Coconut Shell. International Journal of Technology, Volume 10(8), pp. 1488-1497

Fathy, M., Moghny, T.A., Mousa, M.A., El-Bellihi, A.H.A.A, Awadallah, A.E., 2016. Absorption of Calcium Ions on Oxidized Graphene Sheets and Study its Dynamic Behavior by Kinetic and Isothermal Models. Applied Nanoscience, Volume 6(8), pp. 1105-1117

Hasan, S., Iasir, A.R.M., Ghosh, T.K., Gupta, B.S., Prelas, M.A., 2019. Characterization And Adsorption Behavior of Strontium from Aqueous Solutions onto Chitosan-Fuller's Earth Beads. Healthcare, Volume 7(1), pp. 1-18

Hannachi, C., Guesmi, F., Missaoui, K., Hamrouni, B., 2014. Application of Adsorption Models for Fluoride, Nitrate, and Sulfate Ion Removal by Amx Membrane. International Journal of Technology, Volume 5(1), pp. 60-69

Herhady, R.D., Kusnanto, G., Sukarsono, R., Masduki, B., 2003. Sintesis Gelas Keramik Lithium Alumina Silikat untuk Imobilisasi Simulasi Limbah Stronsium-90 (Synthesis of Lithium Alumina Silicate Ceramic Glass for Simulated Immobilization of Strontium-90 Waste). Indonesian Journal of Science and Technology, Volume 4(4), pp. 107-119

Hong, M., Yu, L., Wang, Y., Zhang, J., Chen, Z., Dong, L., Zan, Q., Ruili, L., 2018. Heavy Metal Adsorption with Zeolites: The Role of Hierarchical Pore Architecture. Chemical Engineering Journal, Volume 359, pp. 363-372

Kumar, P.S., Ramakrishnan, K., Kirupha, S.D., Sivanesan, S., 2010. Thermodynamic and Kinetic Studies of Cadmium Adsorption from Aqueous Solution onto Rice Husk. Brazilian Journal of Chemical Engineering, Volume 27(02), pp. 347-355

Kutahyali, C., Eral, M., 2004. Selective Adsorption of Uranium from Aqueous Solutions using Activated Carbon Prepared from Charcoal by Chemical Activation. Separation and Purification Technology, Volume 40(2), pp. 109-114

Kyzas, G.Z., Deliyanni, E.A., Matis, K.A., 2014. Graphene Oxide and its Application as an Adsorbent for Wastewater Treatment. Journal of Chemical Technology and Biotechnology, Volume 89(2), pp. 196-205

Lee, T., Na, C.K., Park, H., 2018. Adsorption Characteristics of Strontium onto $\mathrm{K}_{2} \mathrm{Ti}_{4} \mathrm{O}_{9}$ and PP-G-AA Nonwoven Fabric. Environmental Engineering Research, Volume 23(3), pp. 330-338

Nikazar, M., Gholivand, K., Mahanpoor, K., 2007. Enhancement of Photocatalytic Efficiency of $\mathrm{TiO}_{2}$ by Supporting on Clinoptilolite in the Decolorization of Azo Dye Direct Yellow 12 Aqueous Solutions. Journal of the Chinese Chemical Society, Volume 54(5), pp. 12611268

Nishiyama, Y., Hanafusa, T., Yamashita, J., Yamamoto, Y., Ono, T., 2015. Adsorption and Removal of Strontium in Aqueous Solution by Synthetic Hydroxyapatite. Journal of Radioanalytical and Nuclear Chemistry, Volume 307, pp. 1279-1285

Qiu, L., Feng, J., Dai, Y., Chang, S., 2018. Mechanisms of Strontium's Adsorption by Saccharomyces Cerevisiae: Contribution of Surface and Intracellular Uptakes. Chemosphere, Volume 215, pp. 15-24

Pataya, S.A., Gareso, P.L., Juarlin, E., 2016. Karakterisasi Lapisan Tipis Titanium Dioksida $\left(\mathrm{TiO}_{2}\right)$ yang Ditumbuhkan dengan Metode Spin Coating Diatas Substrat Kaca (Characterization of a Layer of Titanium Dioxide (Tio2) that is Groun using Spin Coating Method on a Glass Substrate). Jurnal kimia, pp. 1-8

Pathak, P., 2017. An Assessment of Strontium Sorption onto Bentonite Buffer Material in Waste Repository. Environmental Science and Pollution Research, Volume 24(9), pp. 8825-8836 
Prihatiningsih, M.C., Basuki, K.T., Brawijaya, P., Saputra, A., 2020. The Adsorption Isotherm and Thermodynamic Studies of Rhenium onto Mesoporous Silica Nanoparticles. Journal of Physics: Conference Series, Volume 1436, pp. 1-8

Ren, G., Wang, X., Huang, P., Zhong, B., Zhang, Z., Yang, L., Yang, X., 2017. Chromium (VI) Adsorption from Wastewater using Porous Magnetite Nanoparticles Prepared from Titanium Residue by a Novel Solid-Phase Reduction Method. Science of the Total Environment, Volume 607-608, pp. 900-910

Sani, A., Rosita, A., Rakhmawaty, D., 2009. Pembuatan Fotokatalis $\mathrm{TiO}_{2}$-Zeolit Alam Asal Tasikmalaya untuk Fotodegradasi Methylene Blue (Preparation of Natural Tioz-Zeolite Photocatalyst from Tasikmalaya for the Photodegradation of Methylene Blue). Jurnal Zeolit Indonesia, Volume 8(1), pp. 6-14

Seidlerová, J., Šafařík, I., Rozumová, L., Šafaříková, M., Motyka, O., 2016. TiO2-based Sorbent of Lead Ions. Procedia Materials Science, Volume 12, pp. 147-152

Song, D., Park, S.J., Kang, H.W., Park, S.B., Han, J.I., 2013. Recovery of Lithium (I), Strontium (II) and Lanthanum (III) using Ca-alginate Beads. Journal of Chemical \& Engineering Data, Volume 58(9), pp. 2455-2464

Sudibandriyo, M., Putri, F.A., 2020. The Effect of Various Zeolites as an Adsorbent for Bioethanol Purification using a Fixed Bed Adsorption Column. International Journal of Technology, Volume 11(7), pp. 1300-1308

Taamneh, Y., Sharadqah, S., 2016. The Removal of Heavy Metals from Aqueous Solution using Natural Jordanian Zeolite. Applied Water Science, Volume 7, pp. 2021-2028

Thahir, R., Rosalin., Khaerunnisa., Laurenz, S., Puspitasari., 2018. Preparasi dan Karakterisasi Titanium Dioksida $\left(\mathrm{TiO}_{2}\right)$ Mesopori Sebagai Adsorben Logam $\mathrm{Cu}(\mathrm{II})$ dan Methylene Blue (Preparation and Characterization of Mesoporous Titanium Dioxide ( $\mathrm{TiO}_{2}$ ) as Adsorbent for $\mathrm{Cu}$ (II) and Methylene Blue). In: Seminar Nasional Hasil Penelitian \& Pengabdian Kepada Masyarakat (SNP2M) 2018 Dec 30, pp. 53-57

Yusan, S., Erenturk, S., 2011. Adsorption Characterization of Strontium on PAN/Zeolite Composite Adsorbent. World Journal of Nuclear Science and Technology, Volume 1(01), pp. 6-12

Zhang, L., Zhang, M., Liu, X., Kang, P., Chen, X., 2010. Sorption Characteristics and Separation of Tellurium Ions from Aqueous Solutions using Nano-TiO2. Talanta, Volume 83(2), pp. 344-350

Zhang, N., Liu, S., Jiang, L., Luo, M., Chi, C., Ma, J., 2015. Adsorption of Strontium from Aqueous Solution by Silica Mesoporous SBA-15. Journal of Radioanalytical and Nuclear Chemistry, Volume 303, pp. 1671-1677

Zhao, S., Asuha, S., 2010. One-pot Synthesis of Magnetite Nanopowder and their Magnetic Properties. Powder Technology, Volume 197(3), pp. 295-297 